\title{
Severe First Trimester Recurrent Intrahepatic Cholestasis of Pregnancy: A Case Report and Literature Review
}

\author{
Andrea G. Hubschmann, MD ${ }^{1}$ Kelly M. Orzechowski, MD, MPH ${ }^{1} \quad$ Vincenzo Berghella, MD ${ }^{1}$ \\ ${ }^{1}$ Division of Maternal Fetal Medicine, Department of Obstetrics and \\ Gynecology, Thomas Jefferson University, Philadelphia, Pennsylvania \\ Address for correspondence Andrea G. Hubschmann, MD, 525 East \\ 28th Street, Box 122, New York, NY, 10065 \\ Am J Perinatol Rep 2016;6:e38-e41.
}

\begin{abstract}
Background Intrahepatic cholestasis of pregnancy (ICP) is a disorder of defective bile acid transport that results in systemic accumulation of bile acids and typically presents in the third trimester of pregnancy with intense pruritus. A positive linear correlation exists between total bile acid level and poor pregnancy outcome, and labor is typically

Keywords

- severe recurrent ICP

- first trimester

- intrauterine fetal demise

- preterm birth induced at 37 weeks gestation to prevent intrauterine fetal demise (IUFD).

Case Study We present the most severe reported case of recurrent ICP presenting early in the first trimester. The patient was delivered by repeat cesarean section at $31^{6 / 7}$ weeks gestation resulting in a viable female infant.

Conclusion latrogenic preterm delivery may be indicated in early-severe recurrent ICP to prevent IUFD, but more research is needed.
\end{abstract}

Intrahepatic cholestasis of pregnancy (ICP) is a disorder of defective bile acid transport with systemic accumulation of bile acids. Women typically present with diffuse pruritus in the third trimester of pregnancy. The incidence of ICP varies geographically with rates as high as 5 to $10 \%$ in Chile, Bolivia, and Scandinavia. ICP is associated with adverse pregnancy outcomes, including meconium staining of the amniotic fluid, fetal asphyxial events, preterm delivery, ${ }^{1}$ and sudden intrauterine fetal demise. ${ }^{2}$ We present the most severe case published in the literature of biopsy-proven recurrent ICP presenting in the first trimester of pregnancy.

\section{Case Study}

A 26-year-old Guatemalan female gravida 6, para 0231 at $7^{5 / 7}$ weeks gestation developed diffuse generalized itching, dark urine, and light colored stools. By patient report, her first pregnancy in 2007 was complicated by ICP at 20 weeks gestation resulting in vaginal delivery at 35 weeks gestation after preterm premature rupture of membranes. Her subsequent pregnancy in 2010 was complicated by ICP beginning at

received

July 2, 2015

accepted after revision

August 25, 2015

published online

October 21, 2015
10 weeks gestation resulting in an intrauterine fetal demise at 27 weeks gestation; she was subsequently delivered by primary cesarean section due to heavy vaginal bleeding during her induction of labor. Meconium staining and intervillous fibrin deposition were identified on placental pathology. In addition, the patient reported a history of intense pruritus with elevated transaminases and bilirubin while using NuvaRing (Merck Corp., Kenilworth, NJ) before pregnancy. She reported no relevant family history.

On physical examination, the patient was in visible distress, continuously itching throughout the interview. She had diffuse excoriations. She had no abdominal tenderness and her examination was otherwise unremarkable and her vital signs were within normal limits. Fetal status was reassuring.

First trimester laboratory studies in the current gestation returned as follows: aspartate aminotransferase (AST) $69 \mathrm{U} / \mathrm{L}$ (normal: 7-35 U/L), alanine aminotransferase (ALT) $107 \mathrm{U} / \mathrm{L}$ (normal: $1-30 \mathrm{U} / \mathrm{L}$ ), total bilirubin $0.5 \mathrm{mg} / \mathrm{dL}$ (normal: $0.1-0.9$ $\mathrm{mg} / \mathrm{dL}$ ), alkaline phosphatase $278 \mathrm{U} / \mathrm{L}$ (normal: 29-92 U/L). Ursodiol $300 \mathrm{mg}$ twice daily was prescribed as well as hydroxizine and diphenhydramine as needed. The total bile
Copyright $\odot 2016$ by Thieme Medical Publishers, Inc., 333 Seventh Avenue, New York, NY 10001, USA. Tel: +1(212) 584-4662.
License terms

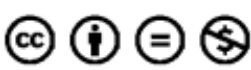


acid level at 13.5 weeks gestation was $243.6 \mu \mathrm{mol} / \mathrm{L}$ (normal: $0-11.3 \mu \mathrm{mol} / \mathrm{L}]$, at which time the dose of ursodiol was increased to $500 \mathrm{mg}$ twice daily, and S-adenosyl methionine $500 \mathrm{mg}$ twice daily was initiated. Repeat bile acids at $16^{3 / 7}$ weeks gestation were $215 \mu \mathrm{mol} / \mathrm{L}$ with a total bilirubin level of $2.8 \mathrm{mg} / \mathrm{dL}$, direct bilirubin $1.5 \mathrm{mg} / \mathrm{dL}$, AST $39 \mathrm{U} / \mathrm{L}$, and ALT 34 U/L. She was referred to hepatology to rule out other differential diagnoses. Additional laboratory evaluation showed: antinuclear antibody negative, antimitochondrial antibody negative, anti-liver kidney microsomal antibody negative, $\alpha$ 1-antitrypsin $179 \mathrm{mg} / \mathrm{dL}$ (normal: 100-300 mg/dL), antismooth muscle antibody positive with a titer of $1: 80$, gamma-glutamyl transpeptidase $36 \mathrm{IU} / \mathrm{L}$ (normal: 0-51 U/L), amylase $52 \mathrm{U} / \mathrm{L}$ (normal: 23-85 U/L), lipase $27 \mathrm{U} / \mathrm{L}$ (normal: 0-160 U/L), ceruloplasmin $97.1 \mathrm{mg} / \mathrm{dL}$ (normal: $20-50 \mathrm{mg} /$ $\mathrm{dL}$ ), and repeat total bile acid level $>191.3 \mu \mathrm{mol} / \mathrm{L}$. Viral hepatology studies were negative for hepatitis $A, B$, and $C$. Abdominal ultrasound revealed a normal size liver without evidence of gallstones; there were no dilated extrahepatic or intrahepatic bile ducts and no signs of portal hypertension or other vascular abnormalities. Due to a positive antismooth muscle antibody, core liver biopsy was performed at $22^{2 / 7}$ weeks gestation to rule out autoimmune hepatitis, primary biliary cirrhosis, and primary sclerosing cholangitis. Histology revealed pure intrahepatic cholestasis (-Fig. 1). The patient experienced worsening, debilitating symptoms at $24^{2 / 7}$ weeks gestation, and cholestyramine $4 \mathrm{~g}$ daily was added to her existing medication regimen. She declined a trial of dexamethasone. At $26^{0 / 7}$ weeks gestation, cholestyramine was increased to $16 \mathrm{~g}$ daily. She was hospitalized at $27^{0 / 7}$ weeks gestation for betamethasone administration and four times daily fetal monitoring, given both the severity of her ICP and her history of a preterm stillbirth. She declined continuous fetal monitoring. She underwent planned repeat caesarean section at $31^{6 / 7}$ weeks gestation after receiving 12 hours of magnesium sulfate for fetal neuroprophylaxis. She delivered a viable female infant weighing 1,758 $\mathrm{g}$ with Apgar scores of 8 at 1 minute, 2 at 5 minutes, and 9 at 10 minutes. The infant required intubation and admission to the neonatal

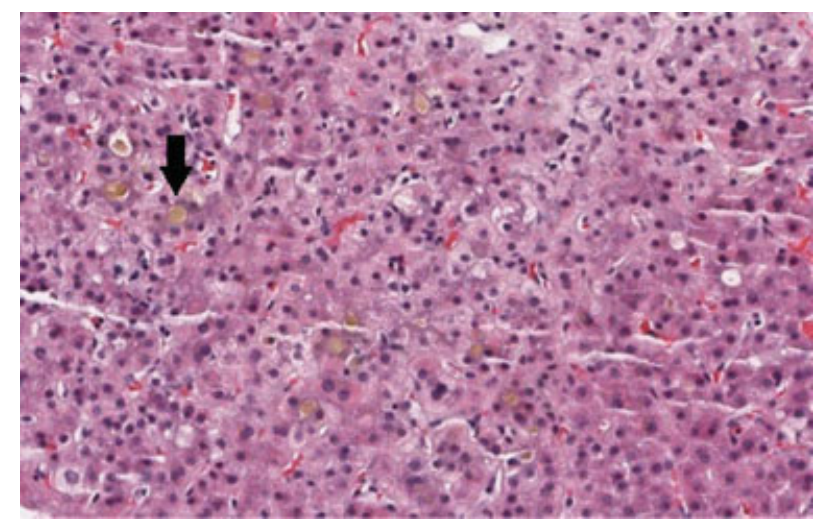

Fig. 1 Core needle liver biopsy. Biopsy shows prominent canalicular cholestasis predominantly in zone 3 , portal tracts are devoid of inflammation. Trichrome and reticulin stains show no increase in fibrosis. PAS-D stain shows Kupffer cell hypertrophy with no stainable iron. PAS-D, Periodic acid-Schiff-diastase. intensive care unit for respiratory distress syndrome and prematurity, and was discharged on day 34 of life in stable condition. The patient's condition improved postpartum and she followed a routine postpartum course.

\section{Comment}

A comprehensive review of the literature was performed using PubMed with the search terms "cholestasis," "ICP," "obstetric cholestasis" AND "pregnancy." Our case represents the highest reported elevated bile acids occurring in the first trimester of pregnancy, with a total bile acid level of $>240 \mu \mathrm{mol} / \mathrm{L}$ at 13 weeks gestation ( - Table 1 ). There are only five additional cases of severe first trimester ICP identified in the literature ${ }^{3-7}$ (-Table 2). It has been proposed that dysfunctional transmembrane molecule in the canalicular membrane of hepatocytes, a condition associated with a recessive gene mutation, may be responsible for decreased bile acid transport and ICP in the setting of elevated estrogen and subsequent downregulation of the partner transporter. Thus, the symptomatology is only seen in hyperestrogenic states such as pregnancy or contraceptive use. $^{8}$ The pathophysiology of fetal demise associated with ICP is not well understood, though a positive linear correlation exists between bile acid level and poor pregnancy outcomes. Glantz et al showed a 1 to $2 \%$ increased risk of adverse events for each additional $\mu \mathrm{mol} / \mathrm{L}$ of bile acid above $40 \mu \mathrm{mol} / \mathrm{L}$. According to this data, our patient could have greater than $30 \%$ risk of adverse outcome. ${ }^{1}$ Furthermore, intrauterine fetal demise associated with ICP appears to be an acute event that can occur within minutes to hours of a reactive nonstress test, ${ }^{9,10}$ thus, fetal distress from ICP is not predicted by conventional methods of fetal surveillance. Animal studies have suggested two possible etiologies of sudden fetal demise associated with ICP. First, elevated bile acids may acutely impair the function of cardiomyocytes resulting in heart failure. ${ }^{11}$ Alternatively, meconium staining may cause vasoconstriction of placental and umbilical blood vessels resulting in fetal acidosis. Rodrigues et al found that while maternal serum bile acid levels decrease with ursodiol treatment, the elevated concentration of bile acids in meconium remained unaltered. ${ }^{10}$ This may explain why negative outcomes are associated with maximum bile acid levels during pregnancy, and improved laboratory values after treatment do not appear to alter the risk of acute fetal demise. ${ }^{1}$ Furthermore, meconium staining complicates 80 to $100 \%$ of deliveries with ICP.

It is generally accepted that ICP is an indication for earlyterm delivery at 37 weeks gestation due to the increased risk of fetal demise. ${ }^{12}$ However, optimal management for women with early recurrent severe ICP is not known. He et al, identified 21 cases of intrauterine fetal demise in women with ICP in which the average gestational age of death was 33.8 weeks, and the earliest gestational age of fetal demise attributable to ICP was at 29 weeks gestation. ${ }^{13}$ Given this limited data combined with the severity of this case's ICP and her personal history of a 27 week fetal demise from ICP, we opted for delivery at 32 weeks gestation, since we believed the risks of prematurity to be less than the risk of intrauterine fetal demise. Additional research is needed to further evaluate the role of iatrogenic preterm delivery 
Table 1 Case laboratory values throughout gestation

\begin{tabular}{|l|l|l|l|l|l|l|l|l|l|}
\hline Laboratory test (normal range) & $\begin{array}{l}7^{3 / 7} \\
\text { wks }\end{array}$ & $\begin{array}{l}11^{6 / 7} \\
\text { wks }\end{array}$ & $\begin{array}{l}13^{4 / 7} \\
\text { wks }\end{array}$ & $\begin{array}{l}16^{3 / 7} \\
\text { wks }\end{array}$ & $\begin{array}{l}17^{3 / 7} \\
\text { wks }\end{array}$ & $\begin{array}{l}19^{3 / 7} \\
\text { wks }\end{array}$ & $\begin{array}{l}2^{3 / 7} \\
\text { wks }\end{array}$ & $\begin{array}{l}27^{6 / 7} \\
\text { wks }\end{array}$ & $2^{6 / 7}$ wks \\
\hline $\begin{array}{l}\text { Aspartate aminotransferase } \\
\text { (units/L) (7-35 units/L) }\end{array}$ & 69 & 98 & & 39 & 30 & 35 & 40 & & 58 \\
\hline $\begin{array}{l}\text { Alanine aminotransferase } \\
\text { (units/L) (1-30 units/L) }\end{array}$ & 107 & 159 & & 34 & 38 & 45 & 56 & & 88 \\
\hline $\begin{array}{l}\text { Total bilirubin (mg/dL) } \\
(0.1-0.9 \mathrm{mg} / \mathrm{dL})\end{array}$ & 0.5 & 2.8 & & 2.8 & 2.3 & 2.2 & 2.2 & & 2.3 \\
\hline $\begin{array}{l}\text { Direct bilirubin (mg/dL) } \\
(0.0-0.3 \mathrm{mg} / \mathrm{dL})\end{array}$ & & & & 1.5 & 1.6 & 1.3 & & & 1.7 \\
\hline $\begin{array}{l}\text { Alkaline phosphatase (units/L) } \\
(29-92 \text { units/L) }\end{array}$ & & & & 235 & & 230 & & & \\
\hline $\begin{array}{l}\text { Total bile acids }(\mu \mathrm{mmol} / \mathrm{L}) \\
(0-11.3 \mu \mathrm{mol} / \mathrm{L})\end{array}$ & & & 243.6 & 215.2 & $>191$ & & & 66.8 & \\
\hline
\end{tabular}

Table 2 Reported cases of early, severe intrahepatic cholestasis of pregnancy

\begin{tabular}{|c|c|c|c|c|}
\hline Reference & $\begin{array}{l}\text { GA at onset } \\
\text { (wks) }\end{array}$ & $\begin{array}{l}\text { Peak TBA } \\
(\mu \mathrm{mol} / \mathrm{L})\end{array}$ & $\begin{array}{l}\text { GA at Peak } \\
\text { TBA (wks) }\end{array}$ & Maternal and fetal outcome \\
\hline $\begin{array}{l}\text { Kirkinen and Ryynänen, } \\
1995\end{array}$ & 13 & 150 & $16-19$ & $\begin{array}{l}\text { Termination of pregnancy at } 19 \text { wks gestation; bile acids } \\
\text { normalized within } 2 \text { wks postprocedure }\end{array}$ \\
\hline Brites et al, 1998 & 10 & 198 & 20 & $\begin{array}{l}\text { Phenobarbital } 150 \mathrm{mg} \text { daily, cholestyramine } 8 \mathrm{mg} \text { daily, } \\
\text { UDCA } 1 \mathrm{~g} / \mathrm{d} \times 21 \mathrm{~d} \text {. Itching and abnormal LFTs persisted } \\
\text { for } 1 \mathrm{wk} \text {. UDCA treatment restarted over } \times 14 \mathrm{~d} \\
\text { Induction of labor at } 36 \text { wks gestation. Female infant } \\
2,050 \mathrm{~g} \text {, Apgar } 9 \text {. Surgery at } 24 \mathrm{~h} \text { of life for intestinal } \\
\text { stenosis. No meconium staining. Complete regression of } \\
\text { maternal symptoms } 2 \text { mo postpartum }\end{array}$ \\
\hline $\begin{array}{l}\text { Chao and Sheffield, } \\
2011\end{array}$ & 16 & 86 & 31 & $\begin{array}{l}\text { Betamethasone } 0.05 \% \text { ointment, hydroxyzine } 10 \mathrm{mg} \text { t.i.d., } \\
\text { UDCA } 300 \mathrm{mg} \text { b.i.d., Triamcinolone } 0.1 \% \text { ointment. } \\
\text { Cesarean section at } 324 / 7 \text { wks gestation secondary to FHR } \\
\text { decelerations of twin B. Twin A Apgar } 8,9,1,505 \mathrm{~g} \text {, } \\
\text { cord pH 7.28. Twin B Apgar 7, 9, } 1,550 \mathrm{~g} \text {, cord pH } 7.21 \text {, } \\
\text { RDS. Both infants discharged at } 22 \mathrm{~d} \text { of life. Resolving } \\
\text { symptoms in postpartum period. Lost to long term } \\
\text { follow-up }\end{array}$ \\
\hline $\begin{array}{l}\text { Konjeti and Selsky, } \\
2012\end{array}$ & 13 & 241.5 & 14 & Not reported \\
\hline Steele, 2012 & 11 & 205 & 16 & $\begin{array}{l}\text { UDCA, rifampicin, weekly Doppler studies. Cesarean } \\
\text { section at } 32^{2 / 7} \text { wks gestation for prolonged fetal } \\
\text { bradycardia. No hepatic disease detected on follow-up. } \\
2,000 \mathrm{~g} \text { male infant with Apgar } 0,5,9 \text {. Infant spent } \\
3 \text { weeks in the neonatal intensive care unit but had no } \\
\text { long-term sequelae }\end{array}$ \\
\hline $\begin{array}{l}\text { Konjeti and Selsky, } \\
2012\end{array}$ & 13 & 241.5 & 14 & Not reported \\
\hline
\end{tabular}

Abbreviations: b.i.d., twice a day; FHR, fetal heart rate; GA, gestational age; LFTs, liver function tests; RDS, respiratory distress syndrome; TBA, total bile acids; t.i.d., three times a day; UDCA, ursodeoxycholic acid.

Note: - Table 2 shows cases reported in the literature whereby severe intrahepatic cholestasis of pregnancy occurred in the first trimester. 
to prevent intrauterine fetal demise in cases of severe recurrent ICP.

\section{References}

1 Glantz A, Marschall H-U, Mattsson L-A. Intrahepatic cholestasis of pregnancy: Relationships between bile acid levels and fetal complication rates. Hepatology 2004;40(2):467-474

2 Geenes V, Williamson C. Intrahepatic cholestasis of pregnancy. World J Gastroenterol 2009;15(17):2049-2066

3 Kirkinen P, Ryynänen M. First-trimester manifestation of intrahepatic cholestasis of pregnancy and high fetoplacental hormone production in a triploid fetus. A case report. J Reprod Med 1995; 40(6):471-473

4 Brites D, Rodrigues CM, Cardoso MdaC, Graça LM. Unusual case of severe cholestasis of pregnancy with early onset, improved by ursodeoxycholic acid administration. Eur J Obstet Gynecol Reprod Biol 1998;76(2):165-168

5 Chao TT, Sheffield JS. Primary dermatologic findings with earlyonset intrahepatic cholestasis of pregnancy. Obstet Gynecol 2011; 117(2 Pt 2):456-458

6 Konjeti R, Selsky N. Intrahepatic cholestasis of pregnancy: a case report. Conn Med 2012;76(3):163-164
7 Steele G. Reflection on a pregnancy complicated by obstetric cholestasis. Pract Midwife 2012;15(9):30-32

8 Trauner M, Meier PJ, Boyer JL. Molecular pathogenesis of cholestasis. N Engl J Med 1998;339(17):1217-1227

9 Lee RH, Incerpi MH, Miller DA, Pathak B, Goodwin TM. Sudden fetal death in intrahepatic cholestasis of pregnancy. Obstet Gynecol 2009;113(2 Pt 2):528-531

10 Rodrigues CMP, Marín JJG, Brites D. Bile acid patterns in meconium are influenced by cholestasis of pregnancy and not altered by ursodeoxycholic acid treatment. Gut 1999;45(3): 446-452

11 Williamson C, Gorelik J, Eaton BM, Lab M, de Swiet M, Korchev Y. The bile acid taurocholate impairs rat cardiomyocyte function: a proposed mechanism for intra-uterine fetal death in obstetric cholestasis. Clin Sci (Lond) 2001;100(4):363-369

12 Roncaglia N, Arreghini A, Locatelli A, Bellini P, Andreotti C, Ghidini A. Obstetric cholestasis: outcome with active management. Eur J Obstet Gynecol Reprod Biol 2002;100(2):167-170

13 He J, Chen L, Liang C. Clinical analysis of fetal death cases in intrahepatic cholestasis of pregnancy [in Chinese]. Zhonghua $\mathrm{Fu}$ Chan Ke Za Zhi 2011;46(5):333-337 